\title{
An Analysis of Errors Committed by Saudi Non-English Major Students in the English Paragraph Writing: A Study of Comparisons
}

\author{
Mohammed Nuruzzaman ${ }^{1}$, A B M Shafiqul Islam*, Israt Jahan Shuchi² \\ ${ }^{\prime}$ Faculty of Languages and Translation, King Khalid University, Abha, Kingdom of Saudi Arabia \\ ${ }^{2}$ Girls' Community College, King Khalid University, Abha, Kingdom of Saudi Arabia
}

Corresponding Author: A B M Shafiqul Islam, E-mail: shafiqju30@gmail.com

\section{ARTICLE INFO}

Article history

Received: December 04, 2017

Accepted: January 24, 2018

Published: February 28, 2018

Volume: 9 Issue: 1

Advance access: January 2018

Conflicts of interest: None

Funding: None

\section{Key words:}

EFL,

Non-English Major,

Errors,

Writing,

Saudi Students,

Comparisons

\begin{abstract}
The present study investigates the writing errors of ninety Saudi non-English major undergraduate students of different proficiency levels from three faculties, who studied English as a foundation course at the English Language Center in the College of Languages \&Translation at King Khalid University, Saudi Arabia in the academic year 2016-17. The findings reveal that the common errors the Saudi EFL students make in writing English paragraphs fall under four categories namely grammar, lexis, semantics and mechanics. Then it compares the categories, types and frequency of errors committed by these three groups of students. Among these categories, grammar has been observed as the most error-prone area where students commit errors the most. The study also posits that among the three groups, the students of the College of Medicine make the minimum errors in all the types and the highest number of errors is committed by the students of Engineering College. The College of Computer Science is in the second position in making errors. The frequency of error types is also found different among these three groups.
\end{abstract}

\section{INTRODUCTION}

Writing is a difficult skill for both native and non-native speakers alike because it requires writers to maintain a balance of multiple issues in the process of writing such as content, organization, grammar, purpose, audience, vocabulary and mechanics. In many of the English as a foreign Language (EFL) academic contexts, as other skills are rarely tested, a learner's success in the target language is measured by his/her competency in writing in that language. According to Fageeh (2011) "many EFL students heavily rely on writing as integral skill to language leaning."

In Alsamadani's (2010) view, writing in a second/foreign language is even more difficult as it is "a complex, challenging, and difficult process" since writers are expected to produce written samples that are syntactically accurate, semantically acceptable and culturally appropriate. Since writing is a challenging task, and English and Arabic linguistic and orthographic systems significantly differ, it is expected that Arab learners of English encounter more difficulties in learning English as a second/foreign language. They usually transfer the stylistic features of Arabic as their first language. They mainly commit errors in writing well-developed paragraphs and essays. Hu- wari, \&Al-Khasawneh (2013) highlight some causes behind their weaknesses of writing like weaknesses in knowledge and understanding of grammatical items, less practice, and educational background. Ansari (2012) delves deep into the difficulties of writing faced by Saudi students and finds out the root cause of their weaknesses which is in school's education system where students are not taught English in a proper way. By defining 'writing' and 'error' separately, this study mainly examines the writing errors committed by some non- English major undergraduate students of different proficiency levels from three colleges-Computer Science, Engineering and Medicine who studied English as a foundation course at English Language Center in the College of Languages \&Translation at King Khalid University, Saudi Arabia in the academic year 2016-17. It also makes a comparison of the types and frequency of errors made by these three groups of students. In the end, the study comes up with some recommendations.

\section{Objective of the Study}

The aims of the present study are two-fold. The primary concern is to find out different types of errors made by Saudi 
EFL learners in writing English paragraphs and then put these errors into different categories. It also makes a comparison of errors committed by the students of three faculties. It also ranks the categories of errors according to their frequency.

\section{Research Questions}

The study tries to seek answers to the following questions:

1. What categories and types of writing errors are committed by level 1 non-English major students of three faculties (College of Medicine, College of Engineering, and College of Computer Science) in the English course at King Khalid University?

2. What are the differences or similarities in the writing errors made by the level 1 non-English major students of these three faculties?

3. What is the ratio of the frequency of different categories of errors?

\section{Significance of the Study}

Though many studies have so far been conducted on writing errors all over the world including Arab contexts, very few in the world and none in the Saudi EFL context have endeavored to compare the types of errors made by the students of different colleges (or different proficiency levels). Moreover, the study is more significant in the sense that it has categorized and measured the types of errors that makes the present study unique in its scope and context. It is hoped that the study would shed light on types and frequency of errors in the English writing samples of different groups and would help both students, teachers and the other stakeholders to design curriculum and the teaching materials accordingly.

\section{DEFINITIONS OF 'WRITING' AND 'ERROR'}

Different researchers have defined 'writing' in different ways from different perspectives. Zamel (1983) describes the process of writing as non-linear, exploratory, and generative which involves the sub-processes of planning, collecting data, drafting, revising, rewriting and editing. Grami (2010 cited in Zuhour and Fatima, 2015) terms writing as a 'complicated cognitive task' because of the fact that it "... demands careful thought, discipline, and concentration, and it is not just a simple direct production of what the brain knows or can do at a particular moment". Alsamadani (2010, p.53) mentions writing as a "complex, challenging and difficult process" which includes multiple skills such as identification of thesis statement, writing supporting details, reviewing and editing. The difficulty of learning/teaching of writing skill is due to the fact that it requires comprehensive knowledge of grammar, suitable vocabulary, writing mechanics, (e.g., punctuation and capitalization), organizational skills, style, and imagination.

Norrish (1983, cited in Taiseer, 2008) terms 'errors' as "systematic deviation when a learner has not learnt something and consistently gets it wrong." He adds that when a learner of English as a second or a foreign language makes an error systematically, it is because he has not learnt the correct form. It is important to make clear that mistakes and errors are not the same. First, mistakes are 'inconsistent deviation' and students make carelessly or unconsciously and they can correct them when they re-check or are brought into their notice. When a learner has been taught a certain correct form, and he uses one form sometimes and another at other times quite inconsistently, the inconsistent deviation is called a mistake. On the other hand, errors occur due to the lack of knowledge or understanding of the issue. Students themselves cannot detect the errors nor can they correct them without others' help. According to Brown (1994a cited in Taiseer, 2008: p.5), mistakes refer to "a failure to utilize a known system correctly whereas errors concern a noticeable deviation from the adult grammar of a native speaker".

\section{Significance of Errors}

Students learn a language through trial and error. As toddlers learn to walk through the process of falling and getting up, we cannot expect that the learners will learn a language without making errors. No doubt, in the process of learning, errors play a significant part. Nevertheless, many educators and theorists in the field of error analysis have focused on the importance of second language learners' errors. According to Corder (1967) and Brown (2000) language learners' errors are important to study because they show the levels of the learners' knowledge. Corder (1967) states that errors are not just something to be eradicated, but rather can be important in and of themselves. He indicates that errors are significant in three different ways. First, to the teachers, they tell them how far towards the goal the learners have advanced and consequently, what remains for them to learn. Second, they provide the researchers evidence of how language is learnt or acquired, what strategies or procedures the learners are employing in their discovery of the language. Third, they are indispensable to the learners themselves, because we can regard the making of errors as a device the learners use in order to learn. Research has provided empirical evidence pointing to the emphasis on learners' errors as an effective means of improving grammatical accuracy (White et al, 1991; Carroll and Swain, 1993). There is a need for students to recognize the significance of errors which occur in their writing, to fully grasp and understand the nature of the errors made. This requires English language teachers to be better equipped, more sensitive and aware of the difficulties students face with regard to grammar, lexis, semantics and mechanics. Taking these ideas into consideration, this study attempts to identify the grammatical, lexical, mechanical and semantic errors which students make in the English paragraph writing in order to help English teachers tackle the problem and to indicate the points of weakness in English writing.

\section{LITERATURE REVIEW}

Many researchers have conducted studies to analyze writing errors made by EFL/ESL learners including Arabic speaking EFL learners. They diagnosed some common types of 
errors in the writing of EFL students all over the world. In order to get a comprehensive picture of the topic, both Arab (including Saudi Arabia, the context of present study) and other EFL contextual studies have been reviewed. In Arab countries where Arabic is the native language and English is the foreign language share almost the same scenario in this field of errors in writing. (Ruwaida, 2015; Taiseer, 2008; Barry, 2014; Salem, 2007).

Ruwaida (2015) investigated problems that Palestinian Arab EFL students faced in developing well-written paragraphs in English. The findings showed that students faced many problems particularly in three areas of writing English composition: sentence structure, paragraph structure, content and organization. She further diagnosed the cause of problems as the transfer of the writing style of their first language (L1 transfer). In the same line, Taiseer (2008) conducted a study to explore the common types of grammatical errors made by Emirati secondary level male students in their English essay writing. The most common and salient grammatical errors which were found in the students' essays included passivization, verb tense and form, subject-verb agreement, word order, prepositions, articles, plurality and auxiliaries.

Similarly, another research was done by Salem (2007) at Al-Azhar University in Egypt. The study reported that most of the students had problems in vocabulary, idioms, cultural knowledge of English, and rhetorical strategies. As the participants were the students of Al-Azhar University, and majoring in English, their errors were also of advanced students. The findings cannot be applicable to other lower grade students or students majoring other subjects.

On the contrary, in Saudi context, a study by Zuhour and Fatima (2015) conducted at Tabuk University explored the common types of errors among 40 female students in the Department of English \& Translation. The findings of the study showed that most language problems were of grammatical problems (in the field of tenses, prepositions, syntactic, subject-verb agreement and the use of articles), punctuation problems (at the level of the absence, the misuse or the addition of punctuation marks) and spelling problems (in the field of substitution, omission, addition, disordering, segmentation and unrecognizable words). As the sample size was small, and difficulty level of writing task is not known, the findings cannot be taken as granted and generalized.

Similarly, Sawalmeh (2013) investigated the errors in a corpus of 32 essays written by 32Arabic-speaking Saudi learners of English from the Preparatory Year Program at University of Ha'il. The results showed that the Arabic speakers in this study committed ten common errors. These errors were: (1) verb tense, (2) word order, (3) singular/plural form, (4) subject-verb agreement, (5) double negatives, (6) spellings, (7) capitalization, (8) articles (9) sentence fragments and (10) prepositions.

Moreover, some other studies (Grami, 2010; Tahaineh, 2010; Kharme and Hajjaj, 1997) also diagnosed other types of errors in Arab students in general. Grami (2010) cited the results of IELTS (International English Language Testing System) report of Saudi students which revealed that they scored comparatively low in all skills $(5.17,4.97$, and 5.81 out of 9 in listening, reading and speaking respectively) but the average in writing skill was the lowest (4.83 out 9). Grami also pointed that although Saudi students study English for six years before joining any university, only a few of them are able to show satisfactory performance in the university entrance examinations.

In a similar Saudi context, Alhaisoni (2012) examined written samples of 100 first-year female Arabic-speaking EFL students of the University of Ha'il. The findings showed that students made a considerable number of errors in their use of articles. This study had a mixed finding because these errors included inter-lingual and intra-lingual transfers.

However, in other EFL/ESL contexts some different types of errors have been diagnosed. For example, Barry (2014) conducted a study on writing errors among 38 students (32 males, 6 females) attending a pre-academic program at Okland University in Michigan. The findings revealed the errors like use of conjunctions, use of conventions of English expression, and word order. Huang (2006) conducted a study about Taiwanese English majors' writing errors based on a web-based writing program. The results depicted that the errors comprised of usage $(55 \%)$, mechanics $(20 \%)$, style $(16 \%)$ and grammar $(9 \%)$. Huang thus concluded that most of students commit writing errors not because of insufficient command of linguistic complexity, but for the usage of incomplete sentences or subject-verb agreement.

Nevertheless, some studies also focused on the causes of the errors made by Saudi students. Ibrahim and Fadi (2013) tried to find out the reasons behind the weakness of writing in English in pre-year students at Taibah University in Saudi Arabia. The findings revealed that grammatical weakness, lack of knowledge and understanding, less practice and educational background were the main reasons of writing errors.

\section{RESEARCH METHODOLOGY}

This study is qualitative in nature where the method of content analysis is used to gather the research results. The content analysis is widely used in social sciences research. This method is used for analyzing the contents of any texts and the texts with errors committed by the participants.

\section{Participants}

The population of the study consisted of 90 (30x3) non-English major undergraduate students from the three colleges- Computer Science, Engineering and Medicine who studied the English foundation course in their first semester in the academic year 2016/2017 at the English Language Center (ELC) in the College of Languages and Translation at King Khalid University, Saudi Arabia. To select the participants, random sampling method was used and all the participants were homogeneous in terms of their linguistic, educational, and socioeconomic background.

\section{Instruments}

Ninety writing sample paragraphs from the semester final exam papers of the participants were collected and used as 
instruments. As the researchers have been teaching writing to the students in the same contexts for more than seven years, their 'notes' taken during classroom teaching have also been used as instruments.

\section{Data Collection}

Writing samples of paragraph from the exam papers were collected as data to analyze. Some common topics (e.g., Yourself, Your Best Friend, A Nice Place to Visit, Your City, and Your Neighborhood) were given and they were asked to write one paragraph in 100-150 words. Sample writings were collected from semester final exams because in exams, students deployed their utmost efforts to secure good grades. So, the exam papers projected their real skills and knowledge in writing. If the participants were asked to write paragraphs just for the research, they might have not taken it seriously. So, samples taken from English writing exams gave the true pictures of the participants' writing errors.

\section{Data Analysis}

After collecting data, the following steps of error analysis specified by Corder (1974) were followed. First, each paragraph was examined word by word and sentence by sentence to ascertain the types and number of errors. Second, they were put under different categories by using coding and thus converted into percentage to examine the frequency. After analyzing the types of errors, the researchers compared the categories and number of errors committed by the students of three faculties for similarities, differences, and connections. Tables 1, 2 and 3 list each category and type of error found in the writing samples in three groups. These Tables showed the total number of errors, their percentages in all the groups and all these findings were shown in a pie chart and a bar graph. At the end of the analysis, Table 4 provides some specific examples of the common errors students made in their paragraph writing.

\section{FINDINGS}

Analyzing data of the three groups of participants, following information has been found to discuss and conclude.

Analysis of errors produced by Saudi EFL learners:

\section{DISCUSSION}

Firstly, the researchers tried to investigate the types of writing errors commonly committed by level 1 students with different proficiency levels of the three colleges. This study used Corder's (1967) taxonomy of writing errors: Grammatical, Lexical, Semantic, and Mechanics. According to the findings of the research, there was a substantial difference in the number of errors made by the three groups (as shown in Figure 1). Participants in group A (College of Medicine) made the lowest number of errors $(\mathrm{N}=117 / 19.83 \%)$ in Table 1 which was followed by group $\mathrm{C}$ (College of Computer Science) that committed a total of 225 (38.14\%) errors in Table 3 and participants in group B recorded the highest number of errors $(\mathrm{N}=248 / 42.03 \%)$ in Table 2 . The findings of total number errors made by the students of these three colleges is depicted in the following pie chart.

Moreover, the study revealed that College of Medicine made less errors in all four categories of errors (Grammati-

Table 1. Categories and types of errors and frequency- group A (college of medicine)

\begin{tabular}{|c|c|c|c|}
\hline Category & Type & Number of Errors & Percentage \\
\hline \multirow[t]{7}{*}{ Grammatical $(47)=7.97 \%$} & 1.Verb tense & 15 & 2.54 \\
\hline & 2.Word order & 6 & 1.02 \\
\hline & 3. Singular/plural & 5 & 0.85 \\
\hline & 4. Relative clause & 3 & 0.51 \\
\hline & 5. Subject-verb agreement & 10 & 1.69 \\
\hline & 6. Subject/verb omission & 2 & 0.34 \\
\hline & 7. Sentence structure & 6 & 1.02 \\
\hline \multirow[t]{7}{*}{ Lexical $(35)=5.93 \%$} & 1. Noun & 3 & 0.51 \\
\hline & 2. Pronoun & 4 & 0.68 \\
\hline & 3. Verb & 4 & 0.68 \\
\hline & 4. Preposition & 10 & 1.69 \\
\hline & 5. Adverb & 4 & 0.68 \\
\hline & 6. Article & 8 & 1.36 \\
\hline & 7.Word form & 2 & 0.34 \\
\hline Semantic $(6)=1.02 \%$ & 1.Word choice & 6 & 1.02 \\
\hline \multirow[t]{3}{*}{ Mechanics $(29)=4.92 \%$} & 1. Punctuation & 8 & 1.36 \\
\hline & 2. Capitalization & 9 & 1.53 \\
\hline & 3. Spelling & 12 & 2.03 \\
\hline Total $=$ out of 590 listed errors & & 117 & 19.83 \\
\hline
\end{tabular}


Table 2. Categories and types of errors and frequency-group B (college of engineering)

\begin{tabular}{|c|c|c|c|}
\hline Category & Type & Number of Errors & Percentage \\
\hline \multirow[t]{7}{*}{ Grammatical $(91)=15.42 \%$} & 1. Verb tense & 26 & 4.40 \\
\hline & 2. Word order & 9 & 1.53 \\
\hline & 3. Singular/plural & 11 & 1.86 \\
\hline & 4. Relative clause & 5 & 0.85 \\
\hline & 5. Subject-Verb Agreement & 24 & 4.07 \\
\hline & 6. Subject/verb omission & 6 & 1.02 \\
\hline & 7. Sentence structure & 10 & 1.69 \\
\hline \multirow[t]{7}{*}{ Lexical $(70)=11.86 \%$} & 1. Noun & 7 & 1.19 \\
\hline & 2. Pronoun & 12 & 2.03 \\
\hline & 3.Verb & 10 & 1.69 \\
\hline & 4. Preposition & 15 & 2.54 \\
\hline & 5. Adverb & 6 & 1.02 \\
\hline & 6. Article & 12 & 2.03 \\
\hline & 7. Word form & 8 & 1.36 \\
\hline Semantic $(12)=2.03 \%$ & 1. Word choice & 12 & 2.03 \\
\hline \multirow[t]{3}{*}{ Mechanics $(75)=12.71 \%$} & 1. Punctuation & 18 & 3.05 \\
\hline & 2. Capitalization & 20 & 3.39 \\
\hline & 3. Spelling & 37 & 6.27 \\
\hline Total $=$ out of 590 listed errors & & 248 & 42.03 \\
\hline
\end{tabular}

Table 3. Categories and types of errors and frequency- group C (college of computer science)

\begin{tabular}{|c|c|c|c|}
\hline Category & Type & Number of Errors & Percentage \\
\hline \multirow[t]{7}{*}{ Grammatical $(75)=12.71 \%$} & 1.Verb tense & 20 & 3.39 \\
\hline & 2. Word order & 8 & 1.36 \\
\hline & 3. Singular/plural & 9 & 1.53 \\
\hline & 4. Relative clause & 3 & 0.51 \\
\hline & $\begin{array}{l}\text { 5.Subject-Verb } \\
\text { Agreement }\end{array}$ & 21 & 3.56 \\
\hline & $\begin{array}{l}\text { 6. Subject/verb } \\
\text { omission }\end{array}$ & 6 & 1.02 \\
\hline & $\begin{array}{l}\text { 7. Sentence } \\
\text { structure }\end{array}$ & 8 & 1.36 \\
\hline \multirow[t]{7}{*}{ Lexical $(68)=11.53 \%$} & 1. Noun & 5 & 0.85 \\
\hline & 2. Pronoun & 9 & 1.53 \\
\hline & 3.Verbs & 10 & 1.69 \\
\hline & 4. Preposition & 19 & 3.22 \\
\hline & 5. Adverb & 5 & 0.85 \\
\hline & 6. Article & 13 & 2.20 \\
\hline & 7. Word form & 7 & 1.19 \\
\hline Semantic $(11)=1.86 \%$ & 1. Word choice & 11 & 1.86 \\
\hline \multirow[t]{3}{*}{ Mechanics $(71)=12.03 \%$} & 1. Punctuation & 17 & 2.88 \\
\hline & 2. Capitalization & 19 & 3.22 \\
\hline & 3. Spelling & 35 & 5.93 \\
\hline $\begin{array}{l}\text { Total }=\text { out of } 590 \text { listed } \\
\text { errors }\end{array}$ & & 225 & 38.14 \\
\hline
\end{tabular}

significance showing the number of errors of different types in each group. 
Table 4. Some specific examples of errors committed by students

\begin{tabular}{|c|c|c|}
\hline Types of Error & Identification of Error & Correct Sentences \\
\hline 1. Verb tense & Last week, I visit Riyadh. & Last week, I visited Riyadh. \\
\hline 2. Word order & He is a student good. & He is a good student. \\
\hline 3. Singular/plural & Every people are very nice. & Every person is very nice. \\
\hline 4. Relative clause & I like my father that is very good. & I like my father who is very good. \\
\hline 5. Subject-Verb Agreement & People in our city is very kind. & People in our city are very kind. \\
\hline 6. Subject/verb omission & My father's first name Sayeed. & My father's first name is Sayeed. \\
\hline 7. Sentence structure & I am go to university. & I am going to university. \\
\hline 8. Noun & $\begin{array}{l}\text { The beautiful of the city attracts many visitors } \\
\text { every year. }\end{array}$ & $\begin{array}{l}\text { The beauty of the city attracts many visitors } \\
\text { every year. }\end{array}$ \\
\hline 9. Pronoun & $\begin{array}{l}\text { My family and I went to a restaurant. They } \\
\text { ate food there. }\end{array}$ & $\begin{array}{l}\text { My family and I went to a restaurant. We ate } \\
\text { food there. }\end{array}$ \\
\hline 10. Verbs & He drive his car fast. & He drives his car fast. \\
\hline 11. Preposition & I go to the restaurant in night. & I go to the restaurant at night. \\
\hline 12. Adverb & Our city is real beautiful. & Our city is really beautiful. \\
\hline 13. Article & In our neighborhood, there is a old park. & In our neighborhood, there is an old park. \\
\hline 14. Word form & $\begin{array}{l}\text { There are a lot of differents between me and } \\
\text { my friends. }\end{array}$ & $\begin{array}{l}\text { There are a lot of differences between me and my } \\
\text { friends. }\end{array}$ \\
\hline 15. Word choice & The exam was beautiful. & The exam was good. \\
\hline 16. Punctuation & $\begin{array}{l}\text { Our neighborhood is nice. It has two parks } \\
\text { three restaurants and two shopping malls }\end{array}$ & $\begin{array}{l}\text { Our neighborhood is nice. It has two parks, three } \\
\text { restaurants, and two shopping malls. }\end{array}$ \\
\hline 17. Capitalization & I like saudi arabia very much. & I like Saudi Arabia very much. \\
\hline 18. Spelling & My frind is Ahmed. & My friend is Ahmed. \\
\hline
\end{tabular}

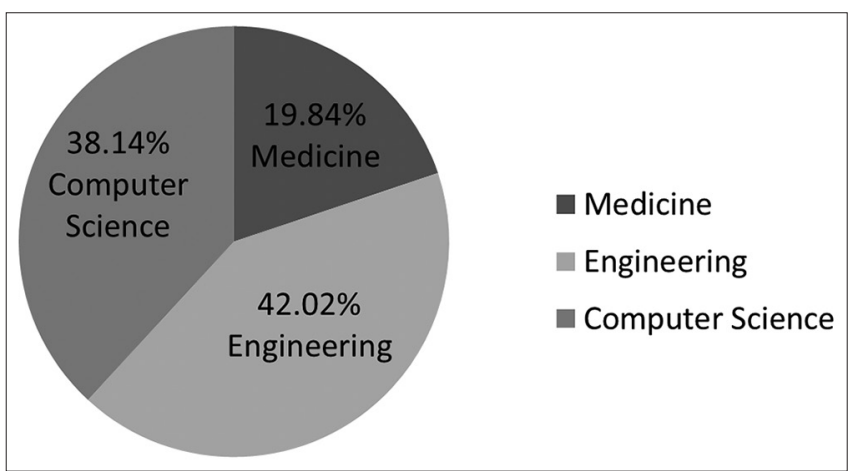

Figure 1. Percentages of total errors committed by three colleges

In general, the results of this study indicate that grammatical error is the most common type of error $(213=36.10 \%)$ made by participants in all three groups, out of the total of 590 errors listed. Similar findings were also found in a contemporary study by Zuhour \& Fatima (2015) at Tabuk University, Saudi Arabia and Napitupulu (2017) in an Indonesian university context. Among three groups, College of Engineering made highest number of errors (15.42\%) and Computer Science (12.71\%) followed it. In grammatical errors, 'verb tense' ranked the highest $(10.33 \%)$ in total in all the three groups. The second area of difficulty in grammar was subject-verb agreement and it scored (9.32\%). The second category of errors was 'mechanics' which consisted $29.66 \%$ of the total errors. In 'mechanics', spelling (14.23\%) was the most frequently committed errors which was followed by capitalization $(8.14 \%)$ and punctuation $(7.28 \%)$.
These findings are in line with the study of Almarwany, M. (2008) which focuses on writing difficulties of EFL secondary school students in Almunawwarh. Lexical errors were in the third position and preposition was the highest $(7.45 \%)$ and next were the article errors $(5.59 \%)$ and verb errors $(4.06 \%)$. In semantic category, 'word choice' comprises $4.91 \%$ of total errors. The findings greatly match the study of Ridha, N.S. (2012) where the researcher investigated the errors in English essay writing of the EFL Iraqi College students where the grammatical and the mechanical errors were the most serious and frequent ones.

On the other hand, in lexical errors, students of Medicine made only $5.93 \%$ of total errors whereas Engineering students made exactly double $(11.86 \%)$ and students of Computer Science committed little less which was $11.53 \%$. Also in semantics, students of Engineering College (2.03\%) and Computer Science (1.86\%) made almost double errors than those of students of Medicine $(1.02 \%)$. These specific data give the general picture of writing difficulties in Arab EFL context. Ruwaida's (2015) research revealed similar results where she stated that in general, Arab students face tremendous difficulties developing well-written paragraphs in English in terms of fluency, content, organization, and accuracy using the acceptable grammatical patterns, punctuation and spelling.

In comparison, the participants of Computer Science College (12.03\%) and Engineering College (12.71\%) committed errors in mechanics almost three times more than those of College of Medicine (4.92\%) and the frequency 


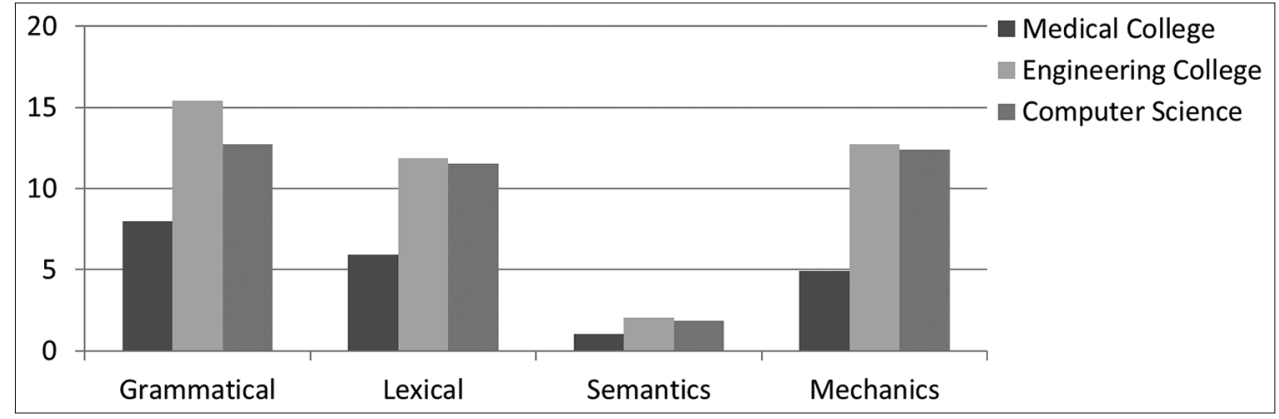

Figure 2. A comparison of error categories in three colleges

of errors of these two colleges was very near. In grammar, engineering students made almost double errors $(15.42 \%)$ than the students of Medicine (7.97\%) but very close to the errors $(12.71 \%)$ made by students of Computer Science. Interestingly, the score of errors in mechanics (12.71\%) made by engineering students was equal to that of grammatical errors of Computer Science students. The study also revealed that total lexical errors of the three groups were almost equal to the errors in mechanics. However, students with different proficiency levels made these types of errors with different frequencies. Participants in Group C had a total of 94 'verb tense' errors that is the highest rate in comparison to Group B and Group A, who made fewer errors in this section-55 and 29 respectively. These results may suggest that inappropriate use of verb tenses is one of the main learning difficulties for all the three groups. However, it should be noted that some 'verb tense' errors seem to be an outcome of negligence in writing rather than lack of L2 proficiency.

Generally, the results of data analysis showed that the errors made by the participants are caused by two major sources: i.e. inter-lingual errors, which occur as a result of L1 transfer, and intra-lingual errors, which occur due to the lack of L2 knowledge. A comparison of participants' errors in all three groups revealed that majority of participants with higher level of language proficiency (i.e. Group A) made more intra-lingual errors than inter-lingual ones whereas those in Group B and C with lower level of language proficiency made more inter-lingual errors due to the L1 interference. The reason behind this fact is that learners find more difficulty in learning English patterns that are similar to, but in some ways different from patterns of their own language. For example, they put 'noun' before 'adjective' (e.g. 'car new' as in Arabic instead of 'new car'). The key to this problem is the fact that they always take resort to literal translation before they form English patterns. Moreover, they translate one language phrase into another language word by word (not phrase by phrase).These findings go parallel with the findings of Abbasi \& Karimian, 2011 and Sadeghi, 2009. Furthermore, it can be stated if the L2 learners utilize the L1 grammatical properties and employ them when writing L2 structures, their use of first language grammatical structures will lead to errors in some circumstances and contribute to the gap between L1 and L2 lexical features. These were also revealed in Ruwaida's (2015) study which stated that helping Arab students to acquire the stylistics of English for developing well-written paragraphs is not easy because they transfer the style of their first language. In addition, they lack the necessary vocabulary for expressing their thoughts appropriately. The results of this research also revealed that the Saudi EFL learners were weak in grammatical rules, vocabulary, spelling, mechanics and semantics which were also in line with some other studies of both Arab and other EFL contexts.

\section{PEDAGOGICAL IMPLICATIONS}

In language teaching, identifying students' errors has always been of utmost interest and great significance to teachers, syllabus designers and test developers. The success of teaching and learning of writing skill does not only depend on the proper identification of the sources of errors but also on the adoption of the appropriate remedial teaching style. And proper identification of errors leads educators to devise appropriate materials and effective teaching techniques, and constructing tests suitable for different levels and needs of learners. Studying the nature of errors enables English language teachers and researchers to have a better understanding of the areas where students face the most difficulties while writing. Being aware of learner errors not only introduces teachers to the knowledge of learner's language, but also help discover the subtle aspects of learning and teaching of a second language. At the same time, studying learner errors involves approaching learning in an intimate way thus enabling teachers to promote appropriate pedagogical tools through understanding the nature of that language. According to Richards et al. (1992), errors help identify strategies which learners use in language teaching, the causes of learner errors, and obtain information on common difficulties in language learning as an aid to teaching or in the development of teaching materials.

In addition to the identification and description of errors, it is also important to correct them. The sources and the types of the errors determine what sort of feedback the teacher might receive since errors provide the teacher with a platform of getting feedback reflecting how effective he is in his/her teaching style and what changes he/she has to make to get better performance from his/her students. So, the findings of error analysis function as facilitator in language teaching in many ways only if the teacher is aware of them and able to make use of them in the teaching process appropriately. Error analysis can also benefit teachers and students simultaneously since errors tell the teacher how far 
the learner has progressed in achieving the goal and what remains for him to learn. Measuring the student's progress, the teacher can reshape his teaching strategies and plans in accordance with the needs of the learner. Furthermore, errors point out the areas that needs further improvement. Additionally, errors are significant data for syllabus designers as they show what items are important to be included or which items needs to be recycled in the syllabus. Keshavarz (1997) maintains that an error-based analysis can give reliable results upon which remedial materials can be constructed.

\section{LIMITATION OF THE STUDY}

The study was conducted only in limited number of samples. It was also done only among Saudi male students of King Khalid University in one semester. So to generalize the results, further longitudinal studies in wider scale in both male and female students are needed. Also, students' perspectives should be studied to find the causes of their writing difficulties and errors.

\section{CONCLUSION AND SUGGESTIONS}

This study identified different errors committed by Saudi EFL students in writing paragraphs. It also presented different types and numbers of errors made by the students of three faculties which indicated their different levels of proficiency. The students of the College of Medicine were found with higher level of proficiency and they made least errors. On the other hand, the students of Engineering College were the weakest and made the highest number of errors. The students of Computer Science made less error than the students of Engineering but more than the students of Medicine. Moreover, the results of the analysis showed that four most common categories of errors were grammar, mechanics, lexis and semantics. In grammatical category, 'verb tense' and 'subject-verb agreement' were the two areas where students committed the highest number of errors. Likewise, 'punctuation' and 'capitalization' were the two error-prone areas in mechanics whereas in lexical category, students made most errors in 'preposition' and 'article'. In addition, in their written paragraphs, inter-lingual errors due to L1 interference are clear. Intra-lingual transfer of Arabic and developmental errors have also been observed in their writing. So, the study shed light on the writing difficulties of the Saudi EFL students and thus helped the instructors take the weak points of the students into consideration while teaching writing.

However, writing instructors should also bear in mind that helping Saudi students in developing their English writing skill is difficult and challenging. Being acquainted with the problems that Saudi learners have and the types of errors that they commit in writing English paragraphs would help the instructors better understand the errors and find useful ways to deal with them. The present study suggests that teachers need to put emphasis on certain aspects of writing in English. They should teach basic grammar rules, tense, subject-verb-agreement, mechanics, lexical items, word order etc. Furthermore, they must make students aware of the differences between English and Arabic structures of phrases and sentences. Thus, this study provides an insight into language learning problems which occur when L2 learners internalize the rules of target language. The errors identified in this study can serve as a useful guide for English teachers and stakeholders to design an effective curriculum for teaching and learning of English as a second language. Saudi students in EFL writing classes should be given ample opportunities for practice in and outside the classroom in order to be acquainted with the appropriate style of writing English composition.

\section{REFERENCES}

Abbasi, M., \&Karimian, A. (2011). An analysis of grammatical errors among Iranian translation students: A gender-based analysis of Iranian EFL learners' types of written errors Insights from inter-language theory. European Journal of Social Sciences, 25(4), 525-536.

Alhaisoni, M. (2012). An Analysis of Article Errors among Saudi Female EFL Students: A Case Study. Asian Social Science-Canadian Center of Science and Education, 8(12), 55-66. Doi:10.5539/ass.v8n12p55

Almarwany, M. (2008). Writing difficulties of EFL secondary school students in Almunawwarh. Unpublished Master's Thesis. Taibah University, Almunawwarh.

Alsamadani, H. A. (2010). The relationship between Saudi EFL students' writing competence, L1 writing proficiency, and self-regulation. European Journal of Social Sciences, 16(1), 53-63.

Ansari, A. A. (2012) Teaching of English to Arab students: Problems and remedies. Educational Research, 3(6), 519-524.

Barry, D. (2014). The impact of native Arabic on English writing as a second language. Clarkston, Michigan: USA.

Brown, H. D. (2000). Principles of language learning and teaching ( $4^{\text {th }} e d$.). White Plains, NY: Longman.

Carroll, S. and Swain, M. (1993). Explicit and implicit negative feedback: An empirical study of linguistic generalizations. Studies in Second Language Acquisition. 15(3), 357-86.

Corder, S. P. (1974). Error Analysis: Perspectives on second language acquisition. London: Longman.

Corder, S.P. (1967). The significance of learner's errors. International Review of Applied Linguistics in Language Teaching, 5(4), 161-170.

Fageeh, A.I. (2011). EFL learners' use of blogging for developing writing skills and enhancing attitudes towards English learning: An exploratory study. Journal of Language and Literature, 2(1), 31-48.

Grami, G. M. A. (2010). The Effects of Integrating Peer Feedback into University-Level ESL Writing Curriculum: A Comparative Study in a Saudi Context (Unpublished doctoral dissertation).Newcastle University.

Huang, S. J. (2006). A case study of EFL students' writing errors on a web-based writing program. A Paper presented at the International Conference \& Workshop on TEFL and Applied Linguistics, Ming Chuan University. 
Huwari, I. F. \& Al-Khasawneh, F. M. (2013). The Reasons behind the Weaknesses of Writing in English among Pre-year Students' at Taibah University. English for Specific Purposes World, 14(38), 1-9.

Ibrahim F. H. \&Fadi M. A. (2012). The Reasons behind the Weaknesses of Writing in English among Pre-year Students' at Taibah University. English for Specific Purposes World, 14(38).

Kharma, N., \&Hajjaj, A. (1997). Errors in English among Arabic speakers: analysis and remedy. Beirut: Librairie du Liban Publishers.

Keshavarz, M. H. (1997). Contrastive Analysis and Error Analysis. Tehran, Rahnama Press.

Napitupulu, S. (2017). Analyzing Linguistic Errors in Writing an English Letter: A Case Study of Indonesian Undergraduate Students. International Journal of Language and Linguistics, 5(3), 71-77.doi: 10.11648/j.ijl1.20170503.12

Norrish, J. (1987). Language Learning and their Errors. London: Macmillan Publisher Ltd.

Richards, J.C. et al. (1992). Dictionary of language teaching and applied linguistics. Essex, Longman.

Ridha, N.S. (2012). The effect of EFL learners' mother tongue on their writings in English: An error analysis study. Journal of the College of Arts. University of Basrah, 60, 22-45.

Ruwaida, A. R. (2015). Challenges Face Arab Students in Writing Well-Developed Paragraphs in English. English Language Teaching, 8(10), 49-58.

Sadeghi, K. (2009). Collocational Differences between L1 and L2: Implications for EFL Learners and Teachers. TESL Canada Journal, 26(2), 100-124.
Salem, M. S. A. S. (2007). The effect of journal writing on written performance, writing apprehension, and attitudes of Egyptian English majors (doctoral dissertation). Retrieved April7, 2017 from https:/etda.libraries.psu. edu/files/final_submissions/434

Sawalmeh, M.H.M. (2013). Error Analysis of Written English Essays: The case of Students of the Preparatory Year Program in Saudi Arabia. English for Specific Purposes World, 40(14), 1-17.

Tahaineh, Y. (2010): Arab EFL university students' errors in the use of prepositions. Modern Journal of Applied Linguistics (MJAL), 2(1), 76-112.

Taiseer (2008). An Analysis of the Common Grammatical Errors in the English Writing made by $3^{\text {rd }}$ Secondary Male Students in the Eastern Coast of the UAE.(Unpublished MA Dissertation). Institute of Education, British University, Dubai, UAE.

Retrieved 20 January, 2014 from https://bspace.buid.ac.ae/ bitstream/1234/225/1/20050055.pdf

White, R., \& Arndt, V. (1991). Process Writing Harlow: London.

Zamel, V. (1983). The Composing Processes of Advanced ESL Students: Six Case Studies. TESOL Quarterly, 17 (2), 165-186.

Zuhour, B. Y. \& Fatima, S. A. (2015). Exploring the most common types of writing problems among English language and translation major sophomore female students at Tabuk University. Asian Journal of Basic and Applied Sciences, 3(2), 7-26. 